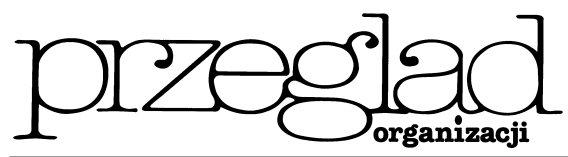

\title{
Procesy uczenia w organizacji i aliansie strategicznym
}

https://doi.org/10.33141/po.2005.01.04

Przegląd Organizacji, Nr 1 (780), 2005, ss. 19-22

www.przegladorganizacji.pl

Małgorzata Dolińska

Towarzystwo Naukowe Organizacji i Kierownictwa (TNOiK)

Wstęp

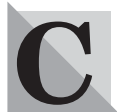

echą charakterystyczną uczącej się organizacji jest jej otwartość na procesy uczenia się, które przebiegają u jej partnerów rynkowych, tj. klientów, dystrybutorów, dostawców, banki, firmy zajmujące się transferem innowacji, współpracowników aliansów strategicznych, w tym działających $\mathrm{w}$ sieci.

Uczenie się organizacji przynosi dodatkowe wartości jej klientom, koncentruje się bowiem na ich usatysfakcjonowaniu, poprzez spełnienie ich potrzeb, oczekiwań, oferowanie im dodatkowych usług.

Struktury, strategie i procesy uczenia się $\mathrm{w}$ aliansie strategicznym powinny być rozwijane $\mathrm{w}$ taki sposób, aby zapewnić efektywną realizację procesów indywidualnego i organizacyjnego uczenia się. W aliansie wykorzystywane są wspólne zasoby jego partnerów podczas kolektywnego uczenia się i transferu informacji zarówno wewnątrz, jak i na zewnątrz aliansu. Wówczas rosną kompetencje jego personelu w zakresie umiejętności uczenia się. Wspólne uczenie się umożliwia rozwój nowych technologii i umiejętności kształtujących produkty nowej generacji oraz tworzy konkurencyjne korzyści, które zapewniają organizacjom współpracującym w ramach aliansu bezpieczną przyszłość.

\section{Procesy organizacyjnego uczenia się}

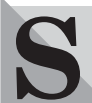

ukces organizacji leży w jej zdolności do uczenia się i tworzenia wiedzy. Musi ona nie tylko reagować na zmiany, ale je antycypować. Uczenie się może być widziane jako proces pozyskiwania nowej wiedzy, motywujący personel organizacji do modyfikacji jego zachowania oraz usprawnienia jej działania. Proces organizacyjnego uczenia się jest realizowany na podstawie indywidualnego i organizacyjnego uczenia się [8, s. 352].

Proces organizacyjnego uczenia oznacza zmiany zachowań organizacyjnych, które są efektem tradycyjnego, empirycznego i cybernetycznego uczenia się.

Tradycyjne uczenie się to proces powiększania kompetencji pracowników poprzez ich aktywny udział w kursach szkoleniowych, seminariach, treningach, konferencjach itp. Realizowany jest również dzięki samokształceniu i wzajemnemu przekazywaniu sobie wiedzy przez pracowników, w tym współpracujących ze sobą w zespołach zadaniowych, projektowych, procesowych. Empiryczne uczenie się to proces zdobywania nowych doświadczeń poprzez praktyczne dzia- łanie. Daje on możliwość zastosowania w praktyce wiedzy zdobytej w trakcie tradycyjnego uczenia się. W skład empirycznego uczenia się wchodzi zdobywanie nowych doświadczeń poprzez bezpośrednią obserwację działania własnego oraz innych ludzi, zespołów i organizacji. W empirycznym sposobie uczenia się wiedza jest efektem doświadczenia personelu oraz obserwacji działań innych. Stosowany jest w nim również benchmarking. Cybernetyczne uczenie się polega na odkrywaniu nowych sposobów widzenia i rozumienia norm rządzących funkcjonowaniem organizacji, a także ich kwestionowaniu i zmianie. Cybernetyczne uczenie się jest procesem odrzucania przyzwyczajeń. Ma na celu zmianę organizacji pracy, doskonalenie systemu wartości, budowanie wizji przyszłości, rozwój kreatywności pracowników, polepszanie współpracy i stosunków społecznych w przedsiębiorstwie $[5,7]$.

O ile tradycyjne i empiryczne uczenie się może być częściowo realizowane przez pojedynczą osobę, to proces cybernetycznego uczenia się jest procesem kolektywnym.

Proces organizacyjnego uczenia się składa się z następujących etapów: rozpoznania, rozdzielania, gromadzenia informacji i wiedzy, jej interpretacji i wykorzystania, tworzenia nowej wiedzy. Rozpoznanie informacji może pochodzić $\mathrm{z}$ bezpośredniego doświadczenia organizacji oraz wewnętrznej pamięci, a także doświadczeń uczestników otoczenia rynkowego. Aby uzyskać informacje o organizacji i jej otoczeniu określane są jej wewnętrzne i zewnętrzne źródła informacji, umożliwiające efektywną realizację jej procesów uczenia się. Uczenie się organizacji różni się od personalnego interpretacją informacji oraz dzieleniem wiedzy pomiędzy jej pracownikami i ich zespołami [3, s. 20].

Proces tworzenia wiedzy obejmuje zespół specyficznych działań i inicjatyw, które podejmuje personel organizacji w celu zwiększenia ilości i jakości posiadanej przez nią wiedzy. Generowanie nowej wiedzy przez człowieka odbywa się głównie przez: rozmowy i słuchanie ludzi, doświadczenia w pracy, intuicję, edukację i trening, analizę istniejącej wiedzy, rozwiązywanie problemów, opracowywanie projektów, uczenie innych ludzi.

Wiedza może powstawać wewnątrz organizacji lub pochodzić z jej otoczenia. W pierwszym przypadku chodzi o stworzenie dogodnych warunków dla personelu do jej kreowania i przepływu wewnątrz organizacji w powiązaniu z jej otoczeniem rynkowym. Znaczna część wiedzy, niezbędna do właściwego funkcjonowa- 
nia organizacji, powstaje poza nią. Wówczas stosowane są rozwiązania absorbujące wiedzę od zewnętrznych ekspertów i konsultantów, współpracowników, otoczenia rynkowego, a także od klientów. Proces transferu wiedzy dotyczy jej przenoszenia i udostępniania innym osobom $[1,2]$.

$\mathrm{Na}$ poziomie organizacji uzyskiwanie nowej wiedzy odbywa się przede wszystkim poprzez wykorzystanie benchmarkingu, obserwację i analizę trendów rozwojowych, gromadzenie doświadczeń, eksperymentowanie. Obecnie alianse strategiczne uznaje się za jedno z zasadniczych rozwiązań, które może być wykorzystane $\mathrm{w}$ procesie pozyskiwania nowej wiedzy przez firmy. Pojawia się tutaj nowy, wyższy poziom organizacyjnego uczenia się - uczenie międzyorganizacyjne [6, s. 15].

\section{Ucząca się organizacja}

$\mathbf{U}$

cząca się organizacja ciągle rozwija swoją wiedzę, zwiększając jej wartość w czasie, i wykorzystuje ją do opracowywania i wdrażania innowacji. Powstająca w niej wiedza jest organizowana, rozdzielania do miejsc jej stosowania i udostępniana użytkownikom, wykorzystywana i doskonalona przez nich w czasie, co czyni organizację ekspertem w zakresie zastosowania przez nią posiadanej wiedzy oraz tworzonych na jej podstawie rozwiązań innowacyjnych. Ideę tę oddaje koncepcja ciągłego rozwoju wiedzy w uczącej się organizacji, który zachodzi pod wpływem pojawiajacych się i/lub antycypowanych zmian w otoczeniu rynkowym oraz wewnątrz organizacji. Zmiany te stają się impulsem do wprowadzania rozwiązań innowacyjnych $\mathrm{w}$ działalności organizacji oraz ich transferu do innych organizacji.

Do źródeł informacji, które umożliwiają uczenie się organizacji należą:

- realizacja indywidualnych planów ciągłego rozwoju kompetencji personelu przez samokształcenie oraz kształcenie, poprzez uczestnictwo w kursach, konferencjach, szkoleniach przeprowadzanych przez przełożonych i specjalistów z zewnątrz, studiowanie;

- pomysły pochodzące od pracowników organizacji, praktyczne zdobywanie doświadczeń, uczenie się na błędach, na bazie doświadczeń innych;

- zespołowe uczenie się organizacji;

- benchmarking wewnętrzny i zewnętrzny;

- analiza działalności konkurentów, produktów konkurencyjnych;

- bezpośrednie kontakty z dostawcami usług, klientami - rozpoznawanie ich potrzeb, oczekiwań, preferencji;

- analizowanie trendów, zjawisk warunkujących zmiany i rozwój wewnątrz organizacji oraz w jej otoczeniu.

Można stosować różne rodzaje uczenia się w organizacji $[3,11]$.

- Adaptacyjne - jest najbardziej podstawową formą uczenia się. Przebiega ono sekwencyjnie, koncentruje się na zagadnieniach i możliwościach, które są związane z obszarem tradycyjnych działań organizacji. Pojawia się ono wraz z zestawem rozpoznanych i nie rozpoznanych ograniczeń, które odzwierciedlają za- łożenia odnośnie do organizacji i jej otoczenia rynkowego.

- Twórcze - pojawia się w sytuacjach, kiedy organizacja rozwiązuje problemy związane z długookresowymi założeniami dotyczącymi jej działalności, tj. formułowaniem misji, wyborem rynków i klientów, planowaniem i realizacją strategii. Wymaga to od personelu organizacji kształtowania nowego sposobu patrzenia na świat i bazuje na rozumieniu systemów, zdarzeń i powiązań między nimi, które zachodzą pod wpływem dynamicznych procesów zmian w otoczeniu rynkowym. Twórcze myślenie łamie reguły i prowadzi do korzyści konkurencyjnych. W procesach innowacji stosowane jest twórcze uczenie się organizacji. Wymaga ono od personelu organizacji kształtowania nowego sposobu patrzenia na świat i bazuje na zrozumieniu systemów, zdarzeń i powiązań między nimi, które zachodzą pod wpływem dynamicznych procesów zmian w otoczeniu rynkowym. Twórcze myślenie łamie reguły i prowadzi do korzyści konkurencyjnych podczas opracowywania, wdrażania i komercjalizacji innowacji.

Uczącą się organizację charakteryzuje pięć zasadniczych składników. Dwa z nich to składowe kultury: orientacja marketingowa i innowacyjność; trzy następne to składowe klimatu organizacji: zdecentralizowane planowanie strategiczne, przywództwo w zakresie umiejętności, struktura organiczna. Składowe elementy kultury i klimatu mają synergiczny wpływ na uczenie się i działalność organizacji [11, s. 67].

Ucząca się organizacja jest zdolna do tworzenia, rozpoznawania i transferu wiedzy, a także modyfikowania swojego zachowania przynoszącego nową wiedzę. Ucząca się organizacje posiada umiejętności w zakresie systematycznego rozwiązywania problemów, eksperymentowania podczas stosowania nowych rozwiązań, uczenia się na podstawie własnego doświadczenia i historii, a także najlepszych doświadczeń innych. Jest w stanie prowadzić transfer wiedzy szybko i efektywnie wewnątrz organizacji oraz w powiązaniu z jej partnerami w obrębie aliansu strategicznego. Uczenie się sprzyja ciągłemu doskonaleniu działalności organizacji wchodzących w skład aliansu strategicznego.

Działalność organizacji uczącej się jest oparta na strukturze sieciowej, w której występują jednostki i komórki posiadające duży zakres autonomii. Wpływ zależności hierarchicznych jest w niej zminimalizowany, a dominującymi relacjami są w niej zależności kooperacyjne.

Uczące się organizacje koncentrują swoją działalność na wytwarzaniu dodatkowej wartości dla klientów oraz kompleksowym rozwoju. Posiadają one możliwości antycypowania swoich działań w celu ich dostosowywania do dynamicznie zmieniających się rynków. Staje się to możliwe dzięki zdecentralizowane$\mathrm{mu}$ planowaniu strategicznemu, które w przypadku uczącej się organizacji jest realizowane elastycznie, zgodnie z aktualnymi celami wyznaczanymi przez zespoły planistyczne. Zespoły te w sposób ciaggły rozpoznaja, przekształcają i rozdzielaja w organizacji wiedzę o rynkach, produktach, technologiach i procesach organizacyjnych. Ich wiedza bazuje na doświadczeniu, eksperymentach, informacji pochodzącej od klientów, 
dostawców, konkurentów, współpracowników funkcjonujących w ramach aliansów strategicznych oraz z innych źródeł.

\section{Uczące się alianse strategiczne}

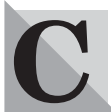

elem aliansu strategicznego jest wzmocnienie potencjału uczenia się, a zarazem budowanie klimatu i kultury wspólnego uczenia się przez jego partnerów. Organizacyjne uczenie wymaga indywidualnych i grupowych umiejętności, w tym w zakresie projektowania struktur zapewniających ciągłe uczenie się, tworzenia wszechstronnej organizacyjnej postawy wzmacniajacej procesy uczenia się. Firmy uczestniczące w partnerskim uczeniu się są w stanie adaptować się do dynamicznego środowiska i zwiększać możliwości spełniania potrzeb klientów. Niezbędnym warunkiem uczenia się aliansu jest możliwość otrzymywania i przekazywania przez jego partnerów informacji przez wewnętrzne i zewnętrzne granice aliansu. Granice mogą być otwierane przez wzmocnienie dialogu, zapewnienie powiązań z klientami i dostawcami, realizację programów wymiany pracy, wdrażanie i sprzedaż innowacji. Bariery pomiędzy partnerami aliansu mogą być przełamywane podczas rozwijania klimatu współpracy w zespołach międzyfunkcjonalnych, w których realizowane są procesy uczenia się. Częste kontakty pomiędzy partnerami aliansu oraz stała interakcja pomiędzy nimi wzmacnia procesy uczenia się [8, s. 353].

Tab. Charakterystyka procesów uczenia się w organizacji i aliansie strategicznym

\begin{tabular}{|c|c|c|}
\hline \multirow{2}{*}{$\begin{array}{c}\text { Proces } \\
\text { uczenia się }\end{array}$} & \multicolumn{2}{|c|}{ Realizowany } \\
\hline & w organizacji & w aliansie strategicznym \\
\hline Tradycyjny & $\begin{array}{l}\text { • udział pracowników w szkoleniach, konferen- } \\
\text { cjach, kursach, seminariach, } \\
\text { • przekazywanie wiedzy - pomiędzy pracownika- } \\
\text { mi w obrębie zespołu, pomiędzy zespołami, } \\
\text { - gromadzenie i wykorzystanie wiedzy, } \\
\text { • gromadzenie dokumentacji w organizacji, } \\
\text { informacji z literatury branżowej, naukowej, } \\
\text { profesjonalnej, z rynku, nt. produktów konkuren- } \\
\text { cyjnych, konkurencji, z targów, wystaw }\end{array}$ & $\begin{array}{l}\text { - szkolenie pracowników firm partnerskich } \\
\text { w aliansie, ich udział w konferencjach, zebra- } \\
\text { niach, seminariach, } \\
\text { - gromadzenie i wykorzystanie w aliansie } \\
\text { wspólnej dokumentacji, informacji, wiedzy, } \\
\text { - pozyskiwanie danych z otoczenia rynkowego } \\
\text { aliansu, } \\
\text { - przekazywanie informacji i wiedzy pomiędzy } \\
\text { firmami partnerskimi }\end{array}$ \\
\hline Emp & $\begin{array}{l}\text { - zdobywanie doświadczenia i umiejętności } \\
\text { w praktyce, podczas wykonywania pracy przez } \\
\text { personel, } \\
\text { - pozyskiwanie personelu z innych firm, w tym } \\
\text { konkurencyjnych, } \\
\text { - kontakty z klientami, dostawcami usług, } \\
\text { - uczenie się na błędach, } \\
\text { - benchmarking wewnątrz oraz na zewnątrz or- } \\
\text { ganizacji, } \\
\text { - wprowadzanie zmian, } \\
\text { - prowadzenie badań marketingowych, analizo- } \\
\text { wanie trendów rozwojowych na rynkach, } \\
\text { - zakup i wdrożenie innowacji, } \\
\text { - gromadzenie doświadczeń, eksperymentowanie }\end{array}$ & $\begin{array}{l}\text { - zdobywanie i wymiana doświadczeń i wiedzy } \\
\text { pomiędzy pracownikami firm partnerskich } \\
\text { aliansu, } \\
\text { - wspólne rozwiązywanie problemów, opracowy- } \\
\text { wanie projektów, } \\
\text { - kontakty z klientami, dostawcami usług, } \\
\text { innymi uczestnikami otoczenia aliansu, } \\
\text { - uczenie się na błędach własnych i partnerów } \\
\text { aliansu, } \\
\text { - benchmarking w obrębie aliansu oraz na } \\
\text { zewnątrz w stosunku do niego, } \\
\text { - analiza rynku, prowadzenie badań marketingo- } \\
\text { wych na potrzeby aliansu, } \\
\text { - wdrażanie innowacji, } \\
\text { - przyjmowanie nowych partnerów do aliansu }\end{array}$ \\
\hline Cybernetyczny & $\begin{array}{l}\text { - budowanie wizji przyszłości, } \\
\text { - korzystanie z usług konsultantów i ekspertów } \\
\text { z zewnątrz, } \\
\text { - analiza i ocena personelu oraz doskonalenie } \\
\text { jego pracy, organizacji działań wykonywanych } \\
\text { w zespole, } \\
\text { - współpraca między zespołami w organizacji, } \\
\text { - realizacja procesu innowacji, twórcze rozwiązy- } \\
\text { wanie problemów, } \\
\text { - opracowywanie strategii zawierającej nowe cele } \\
\text { i rozwiązania do realizacji, } \\
\text { - doskonalenie działalności organizacji i współ- } \\
\text { pracy z uczestnikami otoczenia rynkowego, } \\
\text { zmiana organizacji pracy, } \\
\text { - rozwój kreatywności pracowników, } \\
\text { - tworzenie nowej wiedzy w organizacji }\end{array}$ & $\begin{array}{l}\text { - realizacja procesów innowacji, } \\
\text { - wspólne opracowywanie ekspertyz, projektów } \\
\text { przez partnerów aliansu, } \\
\text { - doskonalenie pracy pracowników i działalności } \\
\text { uczestników aliansu, } \\
\text { - udział partnerów aliansu w realizacji procesów } \\
\text { innowacji, } \\
\text { - stosowanie technik twórczego rozwiązywania } \\
\text { problemów, } \\
\text { - opracowywanie i realizacja strategii dotyczącej } \\
\text { rozwoju i doskonalenia działalności aliansu, } \\
\text { - doskonalenie funkcjonowania aliansu i jego } \\
\text { partnerów, } \\
\text { - poprawa współpracy między partnerami } \\
\text { aliansu, } \\
\text { - tworzenie nowej wiedzy w ramach aliansu }\end{array}$ \\
\hline
\end{tabular}

Źródło: opracowanie własne według [5, s. 24; 6, 8]. 
Uczenie się i transfer wiedzy dla korzyści wszystkich partnerów stają się konkurencyjną korzyścią dla aliansu strategicznego. Zasadniczą częścią wymiany między partnerami uczącego się aliansu jest łatwość dostępu do wspólnej wiedzy posiadanej przez jego partnerów. Dotyczy ona ludzi, urządzeń, systemów zarządzania, informacji na temat różnic w wartościach i realizowanych przez partnerów aliansu celach.

Alianse integrują działalność swoich partnerów, budując między nimi relacje w procesach uczenia się, na podstawie:

- tworzenia lub identyfikowania przez nich nowej wiedzy,

- transferowania i interpretowania wiedzy,

- wykorzystywania wiedzy do realizacji działań umożliwiających osiagnięcie zamierzonych wyników.

Podstawą funkcjonowania organizacji uczących się jest umiejętne zarządzanie ich modelami umysłowymi, które przedstawiaja, testują i doskonalą opinie personelu na temat rzeczywistości. Są one kształtowane przez personel w jego procesach uczenia się oraz podejmowania decyzji. Ich efektem jest kształtowanie wspólnych poglądów i zrozumienia założeń oraz przekonań na temat realizacji celów i doskonalenia współpracy partnerów aliansu [8, 10].

Krytycznym wskaźnikiem sukcesu dla uczenia się aliansów w długim okresie jest umiejętność tworzenia odpowiednich relacji bazujących na procesach uczenia się, które zastępują relacje oparte na władzy. Liderzy w uczących się organizacjach stają się projektantami, nauczycielami, koordynują pracę zespołów, ale nie wydają rozkazów, nie kontrolują ich działania [8, s. 355].

Przyszłe sukcesy i korzyści konkurencyjne aliansu są determinowane przez umiejętności organizacyjnego uczenia się jego partnerów. Sa one podstawą budowania relacji bazujących na współpracy oraz efektywnego wykorzystania wiedzy w procesach uczenia się, zachodzących w obrębie organizacji i aliansu strategicznego. Charakterystykę procesów uczenia się $\mathrm{w}$ organizacji i aliansie strategicznym przedstawia tabela.

Podstawą realizacji procesów uczenia się w organizacji i aliansach strategicznych jest wiedza i kapitał intelektualny.

W skład kapitału intelektualnego wchodzą [3, 12]: - Kapitał ludzki, który zawiera kompetencje i umiejętności pracowników. Kiedy organizacja przyjmuje do pracy zdolnych, wykształconych, posiadających duże doświadczenie i umiejętności pracowników oraz stwarza im właściwe warunki do rozwoju, to wówczas zwiększa swój kapitał intelektualny. W przypadku aliansu strategicznego łączony jest kapitał intelektualny pracowników organizacji partnerskich, które współpracują ze sobą w aliansie.

- Kapitał strukturalny, który składa się z kapitału organizacyjnego, czyli wiedzy zakorzenionej w obszarach procesów uczenia się i innowacji oraz kapitału będącego efektem dobrych relacji z klientami oraz relacji pomiędzy współpracującymi ze sobą w procesach uczenia się partnerami aliansu.

- W ramach aliansów strategicznych powoływane są zespoły zadaniowe (projektowe), w ramach których łączone są kapitały intelektualne pracowników współ- pracujących ze sobą podczas realizacji celów lub rozwiązywania wspólnych problemów. Wówczas występują efekty synergiczne w zakresie wykorzystania kapitału intelektualnego, a także tworzona jest nowa wiedza, która stanowi podstawę realizacji procesów innowacji.

\section{Zakończenie}

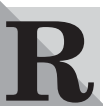
elacje między partnerami aliansu strategicznego kształtują klimat sprzyjający procesom wzajemnego uczenia się, wzrostowi zaufania pomiędzy nimi i korzyściom, które są efektem realizacji wspólnych celów. Uczące się alianse są wspierane przez kooperujacych ze sobą uczestników otoczenia, którzy ułatwiają transfer informacji, zasobów i wiedzy oraz wzmacniają zdolności uczenia się współpracujących ze sobą partnerów.

Rozwój długookresowych, stabilnych powiązań pomiędzy uczącymi się partnerami aliansu prowadzi do dzielenia pomiędzy nimi wiedzy, sprzyja dostępowi do większej liczby źródeł informacji, które przynoszą korzyści wszystkim współpracownikom aliansu oraz mogą prowadzić do ich twórczego uczenia się i realizacji procesów innowacji.

dr hab. Matgorzata Dolińska, prof. Politechniki Lubelskiej Katedra Marketingu

\section{BIBLIOGRAFIA}

[1] BUKOWITZ E.R., WILLIAMS R.L., The Knowledge Management Fieldbook, Financial Time, Prentice Hall, London 1999.

[2] DAVENPORT T.H., PRUSAK L., Working Knowledge: How Organizations Manage What They Know, Harvard Business School Press, Boston 1998.

[3] DOLIŃSKA M., Zarzadzanie wiedza w uczacej się organizacji, „Organizacja i Kierowanie”, nr 4 (102)/2000, s. 13$-26$.

[4] EDVISSON L., Developing Intellectual Capital at Skandia, „Long Range Planning”, 1997, nr 3, vol. 30.

[5] MIKUŁA B., Procesy organizacyjnego uczenia, „Przegląd Organizacji”, nr 12/2000, s. 22-26.

[6] MIKUŁA B., ĆWIKLICKI M., Integracyjna rola zarzadzania wiedza, „Przegląd Organizacji”, nr 4/2001, s. 12-16. [7] MIKUŁA B., ZIĘBICKI B., Organizacja inteligentna a organizacja uczaca się, „Przegląd Organizacji”, nr 5/2000, s. $11-14$.

[8] MORRISON M., MEZENTSEFF L., Learning Alliances - A New Dimension of Strategic Alliances, „Management Decision", 35/5, 1997, s. 351-357.

[9] ROMANOWSKA M., Alianse strategiczne przedsiębiorstw, PWE, Warszawa 1997.

[10] SENGE P., The Fifth Discipline: The Art and Practice of the Learning Organization, Random House, Canberra 1992.

[11] SLATER S.E., NARVER J.C., Market Orientation and the Learning Organization, „Journal of Marketing”, 1995, July, vol. 59, s. 63-74.

[12] STROJNY M., Zarzadzanie kapitatem intelektualnym. Ogólny zarys koncepcji, „Przegląd Organizacji”, nr 7-8/2000, s. $16-19$.

[13] STRATEGOR, Zarzadzanie firma. Strategie, Struktury. Decyzje. Tożsamość, PWE, Warszawa 1995.

[14] ZEMBURA R., Alianse strategiczne $w$ koncepcji marketingu partnerskiego, „Marketing i Rynek”, nr 12/2001, s. $12-18$. 